\title{
Plant and vegetation responses to a changing environment: an alpine issue
}

\author{
Christian Parisod · Sonja Wipf · Sabine Güsewell
}

Published online: 28 October 2010

(C) Springer Basel AG 2010

\section{Introduction}

Botanica Helvetica has traditionally published scientific papers on all aspects of botanical research. The present issue is specifically devoted to alpine plants. It illustrates how they have adapted to the specific environmental conditions of mountain environments in the past and how they respond to human-induced environmental change presently or in the future.

Being based in an Alpine country, Botanica Helvetica has traditionally included a high proportion of studies from the Alps or other mountain regions. The fraction of papers dealing with mountain plants has even been increasing recently. Our most prominent contributions, i.e. those written by famous botanists (e.g. Stebbins 1984) and those most read and most cited in recent years (e.g. Stehlik 2000; Landolt 2006; Parisod 2008) deal with alpine plants.

These observations led us to the decision to prepare a special issue on alpine plants. By devoting an entire issue to this topic, we wish to strengthen the emerging link between the journal of the Swiss Botanical Society and research about mountain plants and vegetation.

\section{Parisod}

Evolutionary Botany, University of Neuchatel, rue Emile-

Argand 11, 2009 Neuchâtel, Switzerland

e-mail: christian.parisod@unine.ch

\section{S. Wipf}

WSL Institute for Snow and Avalanche Research SLF,

Flüelastrasse 11, 7260 Davos, Switzerland

e-mail: wipf@slf.ch

\section{S. Güsewell ( $\square)$}

Institute of Integrative Biology, ETH Zürich, Universitätsstrasse 16, 8092 Zürich, Switzerland

e-mail: sabine.guesewell@env.ethz.ch

\section{Alpine issue(s)}

Alpine plants and mountain vegetation are of particular interest to botanists for several reasons. First, the harsh abiotic conditions, strong environmental gradients and isolated habitats create a particular setting for plant evolution. Population processes and genetic differentiation are expected to differ between lowland plants and alpine plants (Zoller and Lenzin 2006; Stöcklin et al. 2009; Till-Bottraud et al. 2010). Mountain regions also harbor particular plant community types, both at high elevations (Béguin et al. 2006; Gerdol et al. 2010) and in the valleys or forelands (Wallnöfer and Hotter 2008; Prunier et al. 2010a, b).

Second, the Alps have gone through a fascinating history of recurrent climatic changes, glaciations and postglacial recolonisation phases, as well as multiple disturbances. The postglacial vegetation history of the Alps is particularly complex due to the existence of multiple refugia and recolonisation pathways, which have created the specific patterns of species distribution, genetic diversity and vegetation composition observed today. Understanding the processes involves a multitude of questions in the fields of biogeography, phylogeography and paleobotany (Bauert et al. 2007; Gugerli et al. 2009; Mraz et al. 2009; Gobet et al. 2010), which are also highly relevant for predictions of responses to future changes as well as conservation strategies (Gobet et al. 2010; Prunier et al. 2010b),

Third, mountain ecosystems are particularly sensitive to recent anthropogenic disturbances such as land-use changes, nutrient inputs and global warming. They are thus particularly suitable to study the effects of these disturbances (Frei et al. 2010; Pearce et al. 2010; Vittoz et al. 2010). 
Each of these topics is addressed by one or several papers in the present special issue. The collection of papers presented here jointly contributes to a better understanding of plant responses to environmental change-hence the title of this alpine issue.

\section{The future}

As editors, we constantly seek to improve Botanica Helvetica's visibility and attractiveness. Having observed an intrinsic trend for recently published articles to be focused on mountain plants and vegetation, we believe that the journal will benefit from being entirely focused on alpine botany in the future. A tendency towards a narrow thematic focus can be noticed among scientific journals: Some 10-20 years ago, well-established journals with a wide scope were most popular among authors and readers, as evidenced by their high citation indices. These have in recent years been equaled or even surpassed by some journals on more clearly defined topics.

We have consulted botanists from Switzerland and abroad about their opinion on devoting a journal to alpine botany. The generally positive responses encouraged us to pursue this idea.

As from next year, Botanica Helvetica will thus focus on plant research in mountain regions under the new name "Alpine Botany". We hope that the collection of articles published in this special issue will encourage many authors from around the world to submit their next manuscript in this field of research to our journal. We wish to stress that any paper about Swiss plants and vegetation will still be considered for publication given the close link between Switzerland and the Alps. Guidelines for authors will be available soon on the homepage of Botanica Helvetica.

Until now, Botanica Helvetica was edited collaboratively by a team of editors, each of whom was responsible for part of the submitted manuscripts. The editorial responsibility has now been taken over by Prof. Dr. Jürg Stöcklin (University of Basel), who was elected as new editor of the journal at the annual meeting 2010 of the Swiss Botanical Society. He has already done an important work in preparing the transition from Botanica Helvetica to Alpine Botany and has appointed an international editorial board to assist him in editorial decisions. The current team of editors has herewith completed its mission and would like to thank all authors, reviewers and readers for their respective contributions to the existence and success of the journal.

\section{References}

Bauert MR, Kaelin M, Edwards PJ, Baltisberger M (2007) Genetic structure and phylogeography of alpine relict populations of Ranunculus pygmaeus and Saxifraga cernua. Bot Helv 117:181-196

Béguin C, Progin Sonney M, Vonlanthen M (2006) La végétation des sols polygonaux aux étages alpin supérieur et subnival en Valais (Alpes centro-occidentales, Suisse). Bot Helv 116:41-54

Gerdol R, Siffi C, Bombanato, L (2010) Aboveground production and nutrient status of the vegetation of different mire types in the South-eastern Alps (Italy). Bot Helv (this issue)

Frei E, Bodin J, Walther GR (2010) Plant species' range shifts in mountainous areas-all uphill from here? Bot Helv (this issue)

Gobet E, Vescovi E, Tinner W (2010) Ein paläoökologischer Beitrag zum besseren Verständnis der natürlichen Vegetation der Schweiz. Bot Helv (this issue)

Gugerli F, Ruegg M, Vendramin GG (2009) Gradual decline in genetic diversity in Swiss stone pine populations (Pinus cembra) across Switzerland suggests postglacial re-colonization into the Alps from a common eastern glacial refugium. Bot Helv 119:13-22

Landolt E (2006) Zur Kenntnis der Taxonomie und Verbreitung der Alpenpflanzen. Bot Helv 116:79-90

Mraz P, Chrtek J, Singliarova B (2009) Geographical parthenogenesis, genome size variation and pollen production in the arcticalpine species Hieracium alpinum. Bot Helv 119:41-51

Parisod C (2008) Postglacial recolonisation of plants in the western Alps of Switzerland. Bot Helv 118:1-12

Pearce ISK, Britton AJ, Armitage HF, Jones B (2010) Additive impacts of nitrogen deposition and grazing on a mountain mosssedge heath. Bot Helv (this issue)

Prunier P, Garraud L, Köhler C, Lambelet-Haueter C, Selvaggi A, Werner P (2010a) Distribution et régression de la petite massette (Typha minima) dans les Alpes. Bot Helv 120:43-52

Prunier P, Köhler C, Lambelet C, Frossard PA (2010b) Espèces caractéristiques et positionnement syntaxonomique des communautés à petite massette (Typha minima): une contribution au choix des sites de réintroduction d'une espèce alluviale menacée. Bot Helv (this issue)

Stebbins GL (1984) Polyploidy and the distribution of the ArcticAlpine flora-new evidence and a new approach. Bot Helv 94:1-13

Stehlik I (2000) Nunataks and peripheral refugia for alpine plants during quaternary glaciation in the middle part of the Alps. Bot Helv 110:25-30

Stöcklin J, Kuss P, Pluess AR (2009) Genetic diversity, phenotypic variation and local adaptation in the alpine landscape: case studies with alpine plant species. Bot Helv 119:125-133

Till-Bottraud I, Poncet BN, Rioux D, Girel J (2010) Spatial structure and clonal distribution of genotypes in the rare Typha minima Hoppe (Typhaceae) along a river system. Bot Helv 120:53-62

Vittoz P, Camenisch M, Mayor R, Miserere L, Vust M, Theurillat JP (2010) Subalpine-nival gradient of species richness for vascular plants, bryophytes and lichens in the Swiss Inner Alps. Bot Helv (this issue)

Wallnöfer S, Hotter M (2008) Syntaxonomy and site ecology of mixed oak forest communities in the inner and intermedial Alps of Tyrol (Austria). Bot Helv 118:21-43

Zoller H, Lenzin H (2006) Composed cushions and coexistence with neighbouring species promoting the persistence of Eritrichium nanum in high alpine vegetation. Bot Helv 116:31-40 